\title{
The analysis of firms' involvement in internationalisation and determinants of its intensity - an analysis for developing and post-transition economies ${ }^{1}$
}

\author{
Joanna Wolszczak-Derlacz²
}

\begin{abstract}
The study presents the empirical analysis of firms' involvement in different forms of internationalisation: export, indirect export, import, indirect import and finally simultaneous exporting and importing. The analysis is based on firm-level data from the World Bank Enterprise Survey (March 2017 release). The empirical part is divided into two stages. Firstly account is taken of firms' heterogeneity and then a Melitz type analysis of the firms' likeliness of being involved in international activity is performed. Secondly the sample of firms is limited to only those involved in the internationalisation process and then a regression is carried out with the export/import intensity being the dependent variable. The results indicate that determinants of the foreign markets are different from those connected with trade intensity with the exception of the foreign ownership which is the only one associated in the same way with involvement in internationalisation and with its intensity .
\end{abstract}

Keywords: firm-level analysis, trade, internationalisation.

JEL codes: F14, D22, L25.

\section{Introduction}

Traditional trade theories were based on macroeconomic analyses - performed on the level of whole economies/countries (Smith, 1776; Ricardo, 1821). However the elimination of unrealistic assumptions about the homogeneity of companies supplying products both to the domestic and foreign markets (Krugman, 1979, 1980) gave rise to new new trade theory (NNTT) pioneered by Melitz (2003). The main feature of the NNTT is the recognition of significant differences between companies, both in terms of their involvement

\footnotetext{
${ }^{1}$ Article received 6 July 2017, accepted 22 January 2018.

${ }^{2}$ Gdańsk University of Technology, Faculty of Management and Economics, ul. Narutowicza 11/12, 80-233 Gdańsk, Poland, email: jwo@zie.pg.gda.pl. This research was conducted within a project (UMO-2015/19/B/HS4/02884) financed by the National Science Centre, Poland (Narodowe Centrum Nauki - NCN).
} 
in export activity and their characteristics. In particular the aim of the models is to answer the question as to why only some companies decide to enter foreign markets. In the basic Melitz (2003) model, companies differ in terms of productivity, (e.g. as a result of different R\&D spending), and this determines the export activity. The firm's activity can be viewed as a two-stage process: first the company makes a decision about entering the international markets (through export/import or both) and then makes a decision as to how much to trade (the volume of trade).

Consequently the purpose of this study is twofold. First, to identify the differences between companies that provide goods and services only on the domestic market and those that participate in international trade. Building on the original Melitz model (2003) with heterogeneous firms the analysis is extended to other forms of engagement in trade flows, focusing on the probability of a firm becoming an(direct and/or indirect) exporter, an (direct and/or indirect) importer and two-way trader which exports and imports simultaneously. The second aim of the study is to examine what determines the intensity of firm's trade involvement: the export/import volumes. The hypothesis is that the determinants of a presence in foreign markets (the so-called extensive margin e.g. as in Silva, Tenreyro, \& Wei, 2014), are different from the factors connected with the intensity of trade volumes (intensive margin, Chaney, 2008). ${ }^{3}$

In this empirical study the focus is on developing countries and that are either post-transition post or undergoing the transition. The analysis is based on the cross-section firm-level data from the World Bank Enterprise Survey (March 2017 release) covering 140 countries over the period 2006-2016. The empirical part is divided into two stages. Firstly the firm's heterogeneity is taken into account and Melitz type analysis is performed determining the firm's probability of international activity (based on a logit model). Secondly, the sample of firms is limited to only those involved in international operations and the regression with the export/import intensity being the dependent variable is conducted. It is anticipated that this two-stage procedure together with the employment of a large cross-country database considering different forms of internationalisation means that this study can be regarded as an extension of existing literature.

The structure of the paper is as follows: in Section 1 the theoretical background together with the literature review of related empirical studies is presented. In Section 2 the data and crucial descriptive statistics on the charac-

${ }^{3}$ Generally extensive margins refer to the number of exporting firms with an intensive margin to the average export per firm. However the definition of the extensive and intensive margin depends also on the reference level of aggregation e.g. Helpman, Melitz, and Rubinstein (2008) perform the analysis of extensive margin at country level, Hummels and Klenow (2005) at sector-product level while Eaton, Kortum, and Kramarz (2004) at firm-level. Hummels and Klenow (2005) define intensive margin as exporting larger quantities of goods while the extensive margin is the exportation of a wider set of goods. 
teristics of exporters, importers and two-way traders in relation to companies not engaged in the internationalisation process is illustrated. The results of the empirical analysis are presented in Section 3 starting from the model of participation in the internationalisation process and then the model of internationalisation intensity. Section 4 concludes.

The results indicate that productivity, the size of the company and foreign ownership are positively correlated with the probability of internationalisation (in whatever form). The export intensity is found to be negatively associated with firm's productivity and age, and positively with its size and foreign ownership. The last variable is the only one which is similarly important for both margins.

\section{Theoretical background and related empirical studies}

Based on the traditional theories, international trade occurs between economies/countries as the result of differences in absolute advantage (Smith, 1776), comparative advantages (Ricardo, 1821) and later of the differences in the relative level of factors of production (as in Ohlin, 1933). The main disadvantages of the traditional trade theory were the assumptions of perfect competition and constant returns to scale, which eliminated the role of the individual firm itself. The first step to abolish these naive assumptions was the introduction of an imperfect competition theory into international trade analysis, which contributed to the development of the new trade theory (NTT). The basic model of NTT, Krugman $(1979,1980)$ explains intra-industry trade between countries with similar levels of development through economies of scale, imperfect competition and products differentiation from the supply and from the demand side as the result of love of variety - consumer satisfaction increases with the increase in the number of varieties of individual products. Although NTT allows the transition from the analysis of international trade from country/sector level to the analysis conducted at the enterprise level, these models considered the so-called a representative firm. It is assumed that companies are homogeneous in terms of cost functions and demand conditions for their operations and therefore, based on the analysis of the activity of one (representative) enterprise, the conclusions can be generalized to the entire population of enterprises. The departure from unrealistic assumptions about the homogeneity of companies supplying products both to domestic and foreign markets has given rise to the development of so-called new new trade theory (NNTT). In particular NNTT tries to answer the question as to why only some companies decide to enter foreign markets. According to Melitz (2003) a company that decides to enter the foreign market has to cover additional fixed costs (additional to transportation costs and tariffs) connected with entering foreign markets (creating new distribution channels, adapting to foreign regulations, etc.). As a result only the most productive firms decide to enter for- 
eign markets, however, when they enter foreign markets they take advantage of this trade in the form of a higher market share and profits. On the contrary the least productive firms produce only for their domestic market from which they are eventually eliminated by the activity of stronger competitors (exporters). Melitz's (2003) model forms the basis of the theoretical consideration of many others connected with other forms of internationalisation. For example Helpman, Melitz, \& Yeaple (2004) developed the model to explain the heterogeneous firm's decision on the form of foreign market entrance: either through exporting or through foreign direct investment (FDI). According to them the least productive firms serve domestic markets, the more productive ones become exporters and the most productive engage in FDI.

The development of Melitz's (2003) model drew attention to the role of the individual firm's characteristics in explaining international trade flows and gave rise to numerous empirical studies. It is beyond the scope of this paper to present a full literature review, on the contrary the concentration is on the most examined issues (the review of the literature on the NNTT is presented e.g. by Ranjan \& Raychaudhuri, 2016).

One of the most commonly tested hypotheses which come directly from the original Melitz model (2003), is based on the productivity comparison between exporters and non-exporters. The hypothesis assumes that exporters are more productive as a result of self-selection to cover sunk costs associated with starting export operations. In addition companies that want to enter foreign markets in future must be more productive today in order to cover the future costs of the entrance. On the other hand exporters' productivity can rise as a result of so-called learning by exporting when engagement in exporting, promoting knowledge and technology transfers stimulates innovation, motivates a firm to introduce organization adjustments, etc. (Martins \& Yang, 2009).

Wagner (2007), on the basis of a meta-analysis of 54 firm-level studies, concludes that exporters are characterized by a higher productivity and often obtain higher productivity gains than non-exporters. Singh (2010), based on the literature review, indicates that the higher productivity of exporting firms is mainly related to the selection of better companies to export than learning by exporting hypothesis. Martins and Yang (2009) conclude that the impact of exporting upon productivity is higher for developing than for developed economies. Wagner (2012), in a subsequent literature review, underlines the importance of the direction of exporting: noting that firms that sell their products to highly developed countries have higher productivity not only in relation to non-exporters but also in relation to those selling their products to developing countries.

The link between a firm's import activity and its productivity is similar to that of export with the selection of more efficient companies as importers (companies must bear the costs of establishing foreign contacts, obtaining information on foreign suppliers, etc.) and learning by importing hypothesis: companies 
through the purchase of foreign intermediate goods not only have access to cheaper components but also to foreign technology and knowledge (Vogel \& Wagner, 2010). As a result importers become more productive and furthermore can be self-selected as exporters - this is confirmed by the review of the studies done by Wagner (2012), which concludes that the most productive companies are two-way traders - companies that simultaneously export and import.

The link between imports and a firm's performance is mainly focused on the impact of imports of intermediate goods used as a proxy of production fragmentation and offshoring. Schwörer (2013) argues that firms utilizing imported materials and suppliers are more productive, however in some studies, this link is questioned especially underlying the different results for the manufacturing and service sectors (Michel \& Ryck, 2014). Recently empirical analysis has started to take into account even more complex linkages of production sharing e.g. by utilizing the measure of global value chains (e.g. Hagemejer, 2015; Kordalska, Wolszczak, \& Parteka, 2016).

In summary it can be stated that empirical analysis conducted with the use of firm-level data has been mainly focused on export activity although in recent years the research on the impact of offshoring on various aspects of business activity has been growing (and this is largely measured by the statistics related to the importing of intermediate goods). The general conclusion is that exporters and non-exporter differ in many characteristics, amongst others by productivity, size, the level of wages offered (Schank, Schnabel, \& Wagner 2010). The positive correlation between exports and the productivity of firms is generally acknowledged: exporters are more productive than non-exporters, but it is not clear whether this is the result of the selection of the most efficient export companies or rather learning by export. Additionally firms utilizing imported materials and suppliers can use this as a channel to raise their productivity.

In the next section this hypothesis on the basis of the firm-level data covering 140 developing and post and/or under transition economies is verified.

\section{Data and descriptive analysis}

The data used in the empirical study come from the World Bank database: Enterprise Survey (ES), available free of charge at: http://www.enterprisesurveys.org/data. The latest release (dated the 6 March 2017) covering firm-level data from 140 countries mostly developing and transition economies over the period 2006-2016 is used. The sample is cross-sectional in nature with coun-

\footnotetext{
${ }^{4}$ The part of the Enterprise Surveys covering companies from Eastern Europe and Central Asian countries are also known as Business Environment and Enterprise Performance Surveys (BEEPS) and was used in the analysis of a firm's export activity among others by Cieślik, Michałek, \& Michałek (2014).
} 
tries not surveyed annually but at intervals of three or four years. For the final analysis data from all survey waves are used, which are based on standardised methodology with questions common to companies from different countries (as opposed to country-specific surveys). Information is gathered during an interview with top managers and business owners of private companies (state firms with $100 \%$ of government/state ownership are excluded) with the threshold of five employees, from the manufacturing and services sectors. The selection of companies is made on the basis of stratified random sampling with replacement, where the strata refer to the sector, the size of the company and the geographical location within a country. (For more on methods of data collection and processing see World Bank, 2009, 2011). The questionnaire itself contains thirteen sections referring to the characteristics of the establishment, infrastructure, sales and suppliers, competition, capacity, sources of finance, crime, business-government relations, employment, business environment, and performance. The primary objective of the study was to identify the main barriers to the functioning of companies in the market economy, hence the nature of the questions and the choice of countries to sample.

Based on the individual firm's identification number (idstd), the full survey data with ES indicators and firm-level TFP estimates was merged - available also at the Enterprise Survey portal. Altogether in the final database, there are 140550 companies, $57 \%$ are from manufacturing and $43 \%$ from the service sector (the agriculture sector is not covered by the survey). Table 1 presents the distribution of firms across different regions: $22 \%$ of all companies are from sub-Saharan Africa, 20\% from Europe and Central Asia and 19\% from Latin America and the Caribbean. Generally, following the World Bank classification there are $11 \%$ of firms from high-income, $16 \%$ from low-income, while the rest is from middle-income countries (43\% from lower middle and 30\% from the upper middle).

Table 1. Cross-region sample composition

\begin{tabular}{|c|c|c|c|c|}
\hline & All & All in \% & $\begin{array}{c}\text { Export } \\
N=30290\end{array}$ & $\begin{array}{c}\text { Import } \\
N=36512\end{array}$ \\
\hline East Asia \& Pacific (EAP) & 19142 & 13.6 & 16.7 & 12.7 \\
\hline Europe \& Central Asia (ECA) & 28447 & 20.2 & 22.5 & 18.2 \\
\hline Latin America \& Caribbean (LAC) & 26306 & 18.7 & 22.2 & 28.6 \\
\hline Middle East \& North Africa (MNA) & 13721 & 9.8 & 12.0 & 13.3 \\
\hline South Asia (SAR) & 21551 & 15.3 & 11.5 & 8.53 \\
\hline Sub-Saharan Africa (AFR) & 31383 & 22.3 & 15.1 & 18.7 \\
\hline TOTAL & 140550 & 100 & 100 & 100 \\
\hline
\end{tabular}

Source: own compilation based on ES (6 March 2017). 
Since the interest is in a firm's internationalisation based on the answer to the specific questions companies are classified as:

- exporting - the proportion of total sales that are exported directly or indirectly is greater than $1 \%$;

- exporting indirectly - the proportion of total sales that are exported indirectly (through a third party) is greater than $1 \%$;

- importing - the proportion of an establishment's material inputs or supplies is of foreign origin is greater than $1 \%$;

- importing indirectly - if the proportion of total inputs that are of foreign origin is greater than $1 \%$ and at the same time the answer to the question: "were any of these imported material inputs and supplies imported directly?" is "no";

- exporting and importing - simultaneously the proportion of exported total sales is greater than $1 \%$ and the proportion of imported inputs is greater than $1 \%$.

It should be noted that there are some differences between the classifications. For example, information about imports is restricted only to companies from the manufacturing sectors, the notion of "exporting indirectly" and "importing indirectly" is different: the first refers to the situation if at least $1 \%$ of firm's annual sales is derived from indirect exports (at the same time the firm can also export part of its sales directly), while importing indirectly is limited only to those companies where the imports are solely indirect.

In Table 2 the share of sample firms in the respective subsample is presented (percentage of small/medium/large/young firms amongst exporters, importers, etc.). The last column shows the data for all the companies surveyed.

Table 2. The share of small, medium, large and young firms amongst those involved in internationalisation

\begin{tabular}{|l|c|c|c|c|c|c|}
\hline & Exp & $\begin{array}{c}\text { Exp } \\
\text { indirectly }\end{array}$ & Imp & $\begin{array}{c}\text { Imp } \\
\text { indirectly }\end{array}$ & $\begin{array}{c}\text { Exp and } \\
\text { Imp }\end{array}$ & All \\
\hline Small & 21,9 & 29,9 & 30,5 & 48,3 & 14,6 & 47,2 \\
\hline Medium & 35,7 & 38,6 & 36,5 & 36,3 & 33,6 & 33,5 \\
\hline Big & 42,4 & 31,5 & 33,0 & 15,4 & 51,8 & 19,3 \\
\hline Young & 26,6 & 28,4 & 29,0 & 34,1 & 24,1 & 36,1 \\
\hline
\end{tabular}

Source: own compilation based on ES (6 March 2017).

The firms are divided into small (less than 20 employees), medium (from 20 to 99 employees) and large companies (100 employees and more). Exporters and firms involved simultaneously in export and import are mainly large companies (42 and 52\% respectively). The distribution of importers and indirect exporters is more even with slightly more medium firms. A very interesting observation 
is that companies that import inputs solely indirectly are mainly small firms - this is consistent with the observations in the latest joint OECD and World Bank report on the characteristics of global production chains (OECD, 2015).

Next the data for, young companies is shown which are those which started their activity less than 10 years before the survey. It can be observed that firms involved in the different forms of internationalisation are mainly older companies, e.g. the percentage of young exporters is much lower than that in the whole sample analysed (26\% and $36 \%$ respectively). The smallest proportion of companies that started their activities less than 10 years before is for twoway traders $(24 \%)$.

In Table 3 the basic characteristics of firms involved in different form of international activities are presented. Based on a questionnaire, information on their age, qualifications of employees, foreign participation and the use of new technologies is obtained. The variable age (based on the year in which the firm began operations) confirms that firms involved in internationalisation are older than the average age for the whole sample. As far as the qualifications of employees are concerned, the proportion of unskilled workers (out of all production workers) is similar across different companies and that on average around one-third of all production workers are unskilled.

According to the ownership companies can be divided into domestic and foreign : the latter if at least $10 \%$ of ownership is held by foreign individuals, companies or organizations. In the whole sample surveyed there are $10 \%$ of foreign-owned companies (the last column), while $21.5 \%$ are exporters, $16.6 \%$ importers and only $8 \%$ of indirect importers are foreign owned. The largest share of companies with foreign ownership is amongst companies that simultaneously export and import (25\%). These observations confirm that foreign companies are on average more engaged in international trade than domestic ones. Next the information about the percentage of firms using technology li-

Table 3. Characteristics of firms involved in different forms of internationalisation

\begin{tabular}{|l|c|c|c|c|c|c|}
\hline & Exp & $\begin{array}{c}\text { Exp } \\
\text { indirectly }\end{array}$ & Imp & $\begin{array}{c}\text { Imp } \\
\text { indirectly }\end{array}$ & $\begin{array}{c}\text { Exp and } \\
\text { Imp }\end{array}$ & All \\
\hline Age & 21.7 & 20.5 & 21.2 & 18.3 & 23.4 & 17.8 \\
\hline Unskilled & 34.9 & 32.2 & 33.4 & 30.5 & 34.9 & 32.3 \\
\hline Foreign_own & 21.5 & 18.7 & 16.6 & 7.7 & 25.4 & 10.3 \\
\hline Licence_foreign & 23.5 & 23.4 & 19.9 & 12.6 & 26.0 & 14.7 \\
\hline Website & 67.7 & 61.1 & 54.7 & 41.4 & 69.6 & 44.4 \\
\hline Email & 89.5 & 83.9 & 81.5 & 70.1 & 92.5 & 69.6 \\
\hline
\end{tabular}

Source: own compilation based on ES (6 March 2017). 
censed from foreign companies (Licence_foreign), the percentage of firms using the website for business-related activities (Website) and the percentage of firms using E-mail to communicate with clients/suppliers (Email) are presented. Two-way traders are characterised by the highest proportion of firms possessing the above mentioned characteristics e.g. $26 \%$ of two-way traders use technology licensed from foreign companies compared with $15 \%$ of all firms, $70 \%$ of them use a website and $92.5 \%$ E-mail for business activities (45\% and $70 \%$ respectively for the whole sample).

The main conclusion from the Melitz model (2003) is of a positive relationship between the productivity of firms and their engagement in export activity: exporters are more productive than companies that serve only domestic markets. In order to verify this hypothesis the productivity of individual companies as total sales per employee (in logs) $)^{5}$ was calculated. Firstly, the total sales are converted to a common currency (USD) using the official exchange rate and are then deflated to 2009 with a GDP deflator for the US. Figure 1 presents the empirical distribution of the productivity of enterprises engaged in a given form of international activity relative to the control group - companies not involved in any form of internationalisation, e.g. productivity of exporters vs. non-exporters. The productivity distribution for companies not involved in a form of international trade is shifted to the left: companies delivering products/services only to the domestic market have on average a lower level of productivity than those actively participating in international trade. The exception is for indirect importers with an overlapping distribution indicating the lack of the productivity differentials. The difference in productivity is greatest between companies that simultaneously import and export and companies that are not involved in any form of international activity.

Finally it has to be stated that the intensity of different forms of internationalisation varies considerably across countries. For example, the average level of imports is $27 \%$ of a firm's total inputs but Indian companies import only an average $3 \%$ of their inputs (Chinese $4 \%$ ) whilst an Estonian company almost $65 . \%$. The mean value of export as a percentage of annual sales equals $11 \%$ (less than $1 \%$ for Liberian companies and $28 \%$ for those in Malaysia and Tunisia).

These two aspects: determinants of a firm's involvement in international activity and its intensity will be further tested in a strict empirical analysis.

${ }^{5}$ It has to be noted that there are many different productivity measures. Generally they can be divided into single factor productivity such as labour productivity and multifactor measures where the output is related to the number of inputs. The estimation of the firm's total factor productivity in the case of survey data as provided by ES can encounter many difficulties connected with selection and simultaneity issues, with restrictive assumptions imposed on the production function, etc. Because of that the focus of the analysis is on labour productivity. For further discussion of the methods dedicated to productivity measurement see $\operatorname{OECD}(2001,2017)$ and the consideration of firm-level productivity estimates see (Levinsohn \& Petrin, 2003; Katayama, Lu, \& Tybout, 2009). 

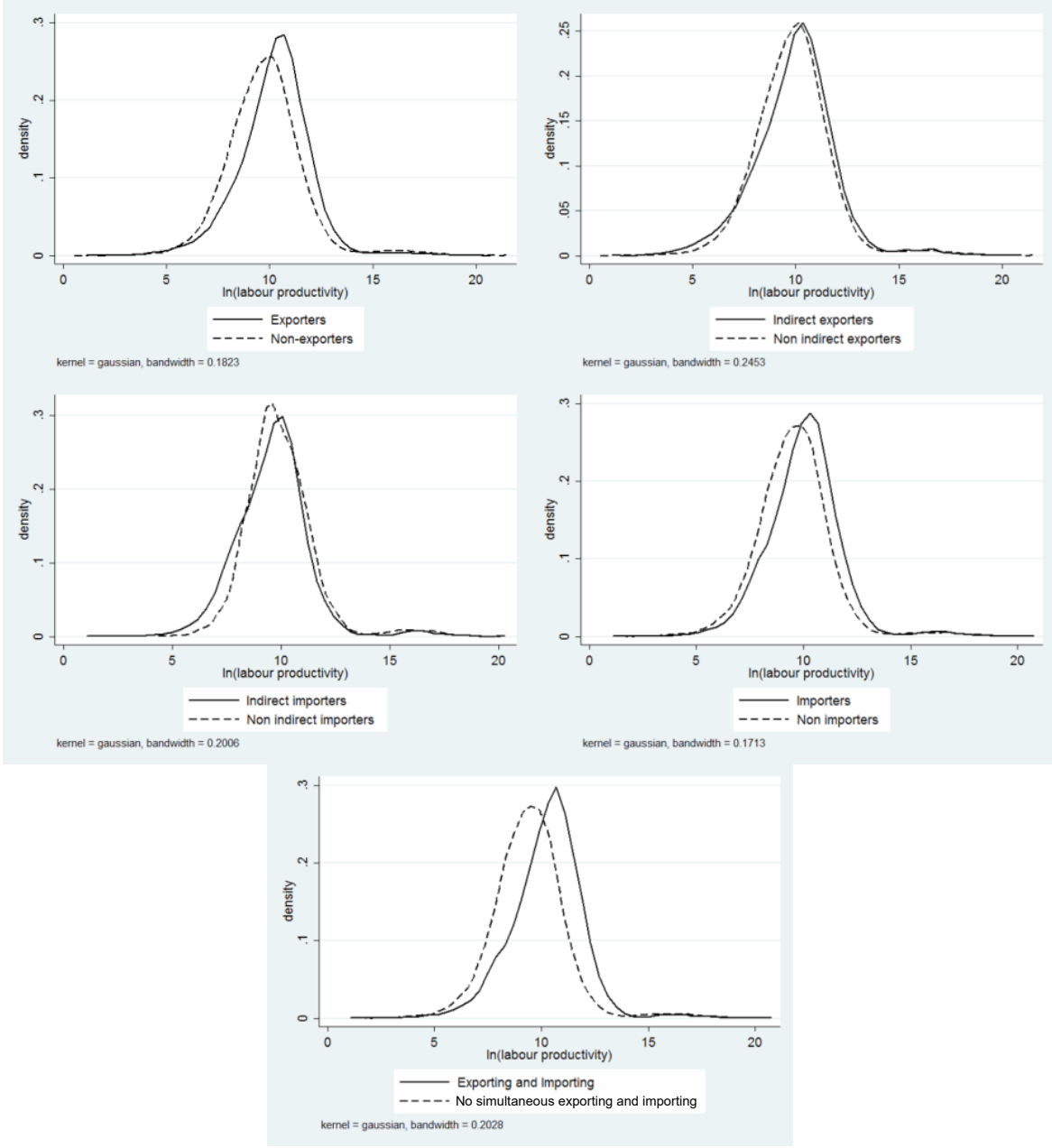

Figure 1. Productivity differences: firms involved in different forms of internationalisation vs. non internationalised firms

Notes: Kernal density estimates, all countries and years pooled together.

Source: own compilation based on ES (6 March 2017).

\section{Empirical models and estimation results}

The analysis was performed in two stages. Firstly the determinants of firm's involvement in international activity were checked - what are the factors influencing a firm's decision as to whether to export/import or not. Secondly, the analysis is limited only to those companies which are active in international markets and an endeavour is made to try to answer the question as to what are the determinants of how much to export/import or both. 


\subsection{Participation in internationalisation}

In the first step of the empirical analysis, the Melitz type model assessing the crucial determinants of firms' international activity is estimated, as in eq. (1):

$$
y_{i t}= \begin{cases}1, & \beta_{0}+\beta_{1} \operatorname{Prod}_{i t}+\beta X_{i t}+D_{c}+D_{t}+D_{s}+\varepsilon_{i t} \\ 0, & \text { else },\end{cases}
$$

where: $y_{i t}$ - is the binary dependent variable which takes value one if a firm is involved in the internationalisation process and zero otherwise. For example for exporters $y_{i t}=1$, for non-exporters: $y_{i t}=0$, analogously for importers and non-importers and other forms of direct or indirect internationalisation. The estimation method is the logit model with clustered robust standard errors with strata weights. Following the literature (Melitz \& Redding, 2014) as the main determinant of the decision either to take part in internationalisation process or not the firm's productivity $\left(\operatorname{Prod}_{i t}\right)$ is considered, expressed in logarithms and calculated as presented in the previous section. Additionally, a number of control variables $X_{i t}$, are included: $S i z e_{i t}$, size of the company expressed as the (log) of the total number of permanent employees, $A g e_{i t}$ based on the year in which the firm began operations, proportion of unskilled workers (of all production workers) (Unskill ${ }_{i t}$ ) and the information as to whether the company is under foreign ownership $\left(\right.$ Foreign $\left._{i t}\right)$. Additionally, the specification by country $\left(D_{c}\right)$, sector $\left(D_{s}\right)$ and time $\left(D_{t}\right)$ dummies is augmented.

The results are presented in Table 4 in the Appendix. The analysis is started with the simplest regression with the productivity $\left(\operatorname{Prod}_{i t}\right)$ being only one regressor (Columns 1, 3, 7, 10 and 13), next the regression is estimated with Size, Unskill, Age, Foreign (excluding Prod as potentially correlated with the former $\left.{ }^{6}\right)$ and finally the model with $\left(\operatorname{Prod}_{i t}\right)$ and all control variables is estimated (Columns: 3, 6, 9, 12 and 15). The results indicate the positive correlation between the productivity and the decision of participation in the different form of internationalisation with the exception of indirect importing. For the rest, either when the regression with only Prod is estimated or augmented of all other control variables, the coefficient is positive and statistically significant. Additionally, it appears that firms which are bigger are more likely to be involved in international activities (positive and statistical coefficient of Size for all specifications) and similarly in a firm with foreign ownership (with the exception of indirect exporting and indirect importing when the coefficient of Foreign is not statistically significant). Neither the age of the firm nor the proportion of unskilled workers are correlated with the firm's activity on international markets.

\footnotetext{
${ }^{6}$ However the partial correlation between Prod and other variables is not high: Prod/Size $=0.13 ; \mathrm{Prod} /$ Unskill $=0.09$, Prod $/$ Age $=0.08$, Prod $/$ Foreign $=0.1$.
} 
Additionally the cross-country heterogeneity is estimated, conducting the estimates for the subgroups of countries classified according to income levels: high income versus low income (following the World Bank classification). The results are presented in Table 5. This time only the final regression with Prod and all other control variables is shown. Most of the results are very similar to the previous ones and there are no significant differences between high and low-income countries. The exceptions are the opposite sign of the coefficient of size in case of indirect importers for high and low-income countries. Due to the very limited number of observation for high-income countries no strong conclusions are drawn. Next the ratio of unskilled workers is statistically significant in case of importers from high-income countries and two-way traders from low-income countries - in both cases the association is negative: the higher the proportion of unskilled workers the lower the probability of involvement in a form of internationalisation. Finally, in the case of indirect exporters, the positive association between Prod and involvement in indirect exporting is statistically significant only in the case of low-income countries. Additionally the analogous estimates for firms from different regions were run (as classified in Table 1). Again the estimates yield similar results, however, some differences between firms from distinct regions have to be acknowledged. ${ }^{7}$ For exporters Prod, Size and Foreign are positively and statistically significantly correlated with the probability of engagement in this form international activity, the exception is foreign ownership where the coefficient is not statistically significant in case of companies from the Middle East \& North Africa. Additionally Unskill is negatively associated with exporting from firms from sub-Saharan Africa. For firms from LAC Foreign is negatively associated with the probability of indirect exporting. As in previous estimates importing activity is positively associated with Prod, the coefficient is not statistically significant in the case of companies located either in EAP or AFR, positively with size (the coefficient is statistically significant for all regions), negatively with Unskill in case of EAP and AFR and positively in the case of MNA, positively with Foreign - but not statistically significant for firms from MNA and SAR. Additionally the probability of importing and simultaneous importing and exporting is higher for older firms from SAR.

Furthermore deeper sector heterogeneity was investigated. In the case of exporters the eq. 1 can be estimated separately for firms from manufacturing and services. For importers the survey results refer only to manufacturing companies. The proportion of exporters from manufacturing is $80 \%$ whilst from services $20 \%$. Table 6 presents the results when the division of sectors is employed (note that sector dummies are still used since they are at the 2-digit level). The variable referring to unskilled labour was not included here in equa-

\footnotetext{
${ }^{7}$ Due to space constraints the detailed results are not shown here, but they are available from author on request.
} 
tions since there was no information for services in this respect. In the case of exporters the results for manufacturing and services are very similar. For indirect exporters neither productivity nor foreign ownership impacts probability in any significant way.

Finally estimates with additional variables describing the level of technology were run (e.g. whether the firm uses technology licensed from a foreign company and uses email to communicate with clients/suppliers), and capital: proxied by the replacement value of machinery, vehicles and equipment. The additional variables seem to be statistically significant and positively correlated with the internationalisation process whilst the original conclusions still hold. ${ }^{8}$

\subsection{Intensity of internationalisation}

In the second stage of the analysis the sample is restricted to firms which are involved in any form of internationalisation and then attention is turned to the determinants of the intensity of the process following the eq. 2 :

$$
y_{i t}=\beta_{0}+\beta_{1} \operatorname{Prod}_{i t}+\beta X_{i t}+D_{c}+D_{t}+D_{c}+\varepsilon_{i t} \text {, }
$$

where: $y_{i t}-$ is log value of trade (export, import), and the independent variables are defined as before. The analysis is started employing OLS with country, time and sector dummies and clustered robust standard errors. Table 7 in the Appendix presents the results. It was found that exporting intensity is negatively associated with productivity (negative and statistically significant coefficient on Prod - Column 1 and 2). This indicates that rather less productive firms increase export volume. Additionally bigger firms export more but size is not statistically significant in the case of indirect export and import. The higher share of inputs imported indirectly is identified for smaller firms (a negative and statistically significant parameter on Size in Column 4). There is a positive correlation between the share of unskilled labour and export volume. Furthermore the results indicate that younger firms are more intensively engaged in the internationalisation process: the higher the firm's age, the lower the intensity of internationalisation. Finally the intensity of all forms of internationalisation (with the exception of indirect importing) is higher for foreign-owned companies.

Analogous to the analysis presented in the previous section the regression was run separately for firms from high and low-income countries. Table 8 in the Appendix shows the results. The productivity is associated with trade intensity

\footnotetext{
${ }^{8}$ However the models augmented with those proxies of technology and capital are characterised by a considerably lower number of observations, the number of observation decreases by around $1 / 3$ depending on the specification. The detailed results are available from the authors on request.
} 
only in case of companies from high-income countries: negatively with export volume and positively with import volume. For two-way traders productivity has a statistically significant coefficient for low-income countries. The next difference emerges is size in the case of importing intensity: bigger firms import less in the case of high-income countries. Interestingly the higher the share of unskilled labour, the higher the export intensity in the case of low-income countries. For Age and Foreign there are no distinct differences between companies from high and low-income countries: older firms export less and those with foreign ownership are characterised by higher trade intensity.

Additionally regression 2 was estimated separately for different regions. ${ }^{9}$ As far as exporting activity is considered the negative correlation between trade and Prod as well as the positive correlation between Size and exporting is confirmed only for companies from Europe \& Central Asia. For the rest of the regions the coefficients are not statistically significant. For importing: Prod is positively correlated with trade intensity for EAP, ECA and SAR. Interestingly Size has a positive impact on the import volume for EAP but it is negative for LAC and MNA. The remaining results do not show regional heterogeneity and are in line with previous estimates.

Finally the division of estimates according to the manufacturing and service sectors indicate that in case of services the only single, statistically significant variable is productivity.

\section{Conclusions}

In this study a two-stage analysis of a firm's involvement in different forms of internationalisation: export, indirect export, import, indirect import and finally simultaneous exporting and importing was performed. The analysis was based on the firm-level data from the World Bank Enterprise Survey (March 2017 release) covering private companies from 140 counties (developing, post or under transition).

The empirical part was divided into two stages. Firstly a firm's heterogeneity was taken into account and then a Melitz type analysis determining the firm's likelihood to be active in the international market (extensive margin) was taken into account. Secondly the sample of firms was limited to only those involved in the internationalisation process and the regression was performed with export/import intensity being the dependent variable (intensive margin).

The results indicate that productivity, the size of the company and foreign ownership are positively correlated with the probability of internationalisation (foreign ownership is not important for indirect export and indirect import).

\footnotetext{
${ }^{9}$ Due to space constraints the detailed result are not presented but they are available from the authors on request.
} 
Some heterogeneity is found as far as companies from different regions are concerned e.g.: high versus low-income countries. For export the regressions were also estimated separately for the manufacturing and service sectors where the only difference refers to indirect export and the loss of statistical significance by the variable describing foreign ownership in the case of manufacturing.

As far as the intensity of internationalisation is concerned a firm's productivity was found to be negatively associated with export volume, its size positively with export and negatively with indirect import whilst there is a general consensus that companies with foreign ownership trade more. Additionally older companies were characterised by lower export, indirect export and simultaneous export and import volumes. Some interesting findings refer to the separate estimates for high and low-income countries. Specifically the productivity was associated mainly with trade intensity in the case of companies form high-income countries: negatively with export volume and positively with import volume. The next difference which emerges is size in case of importing intensity: bigger firms import less in the case of high-income countries.

Based on the results it can be said that determinants of a presence on foreign markets are different from the factors connected with the intensity of trade volumes. Foreign ownership is the single variable that is important for both margins.

Some limits of the study have to be acknowledged. Due to the nature of the data it was not possible to conduct panel analysis. Lagged variables could not be included e.g. lagged company productivity which could, to some extent, solve the problem of endogeneity. Similarly the firm's prior internationalisation status was not provided (e.g. information as to whether a company was involved in international activity in the last year) which would capture the persistence of international behaviour, interpreted as sunk costs. Due to these limitations it was decided not to employ the Heckman (1979) selection model where the information about past internationalisation activity would be a natural choice as a selection variable. It is to be hoped that this limitation can be overcome in future studies as and when new (e.g. panel) data becomes available. Future research based on panel firm-level data could be dedicated to the survival analysis of exporting/importing, the impact of national-regional regulation on the firm's internationalisation and an analysis of the relationship between access to imported intermediate inputs and exporting activity. 


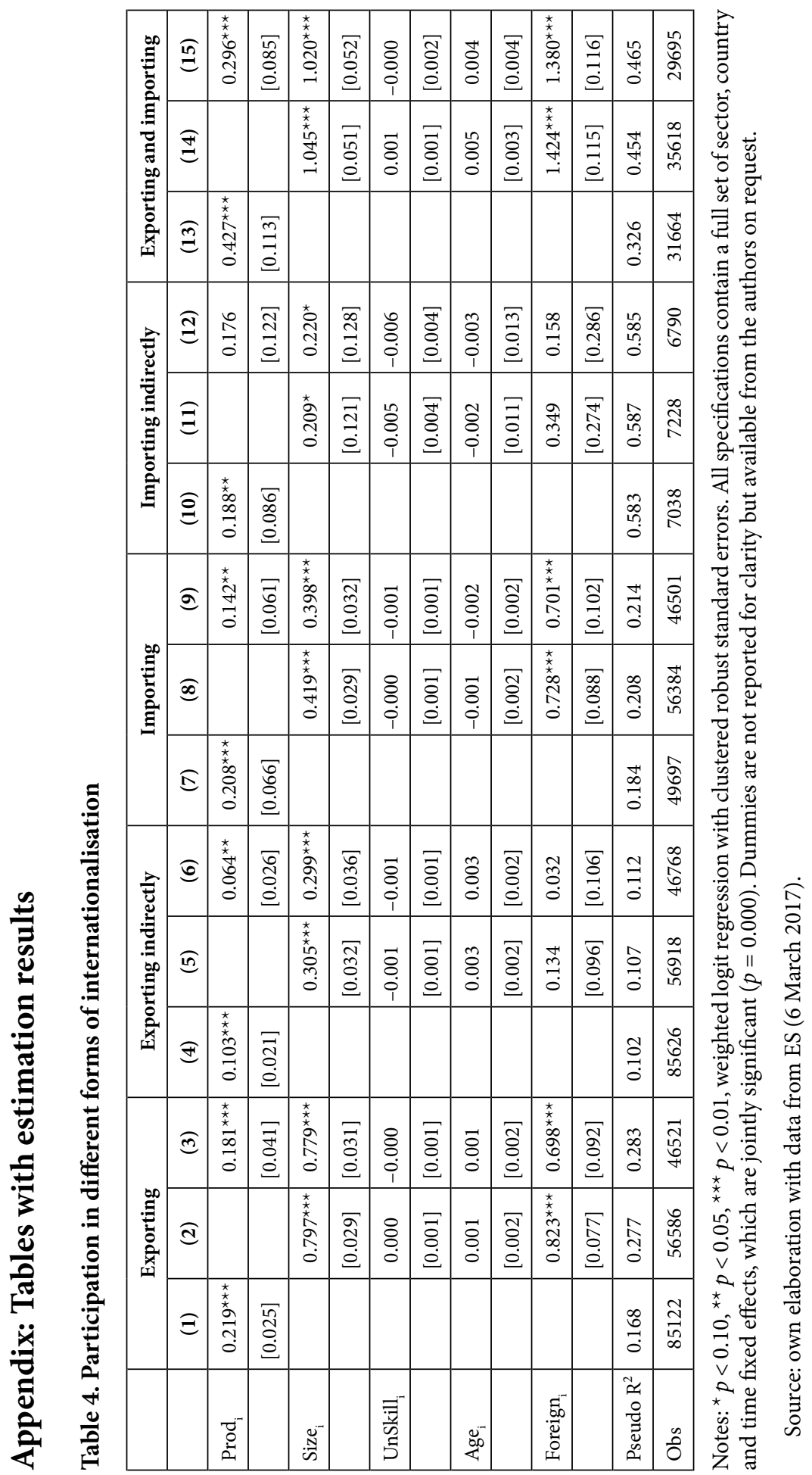


Table 5. Participation in different forms of internationalisations: high versus low income countries

\begin{tabular}{|l|c|c|c|c|c|c|c|c|c|c|}
\hline & \multicolumn{2}{|c|}{ Exporting } & \multicolumn{2}{c|}{$\begin{array}{c}\text { Exporting } \\
\text { indirectly }\end{array}$} & \multicolumn{2}{c|}{ Importing } & \multicolumn{2}{|c|}{$\begin{array}{c}\text { Importing } \\
\text { indirectly }\end{array}$} & \multicolumn{2}{c|}{$\begin{array}{c}\text { Exporting and } \\
\text { importing }\end{array}$} \\
\hline Income & High & Low & High & Low & High & Low & High & Low & High & Low \\
\hline & $\mathbf{( 1 )}$ & $\mathbf{( 2 )}$ & $\mathbf{( 3 )}$ & $\mathbf{( 4 )}$ & $\mathbf{( 5 )}$ & $\mathbf{( 6 )}$ & $\mathbf{( 7 )}$ & $\mathbf{( 8 )}$ & $\mathbf{( 9 )}$ & $\mathbf{( 1 0 )}$ \\
\hline Prod & $0.216^{* * *}$ & $0.107^{* * *}$ & -0.026 & $0.048^{*}$ & $0.202^{* * *}$ & $0.129^{* *}$ & 0.208 & 0.108 & $0.372^{* * *}$ & $0.207^{* * *}$ \\
\hline & {$[0.049]$} & {$[0.028]$} & {$[0.061]$} & {$[0.028]$} & {$[0.043]$} & {$[0.057]$} & {$[0.478]$} & {$[0.131]$} & {$[0.067]$} & {$[0.069]$} \\
\hline Size & $0.748^{* * *}$ & $0.810^{* * *}$ & $0.281^{* * *}$ & $0.350^{* * *}$ & $0.324^{* * *}$ & $0.443^{* * *}$ & $-0.259^{* *}$ & $0.236^{* *}$ & $0.859^{* * *}$ & $1.141^{* * *}$ \\
\hline & {$[0.042]$} & {$[0.047]$} & {$[0.048]$} & {$[0.052]$} & {$[0.046]$} & {$[0.044]$} & {$[0.130]$} & {$[0.112]$} & {$[0.066]$} & {$[0.076]$} \\
\hline Unskill & -0.000 & -0.002 & 0.001 & -0.003 & $-0.003^{* *}$ & -0.002 & -0.005 & -0.007 & -0.002 & $-0.004^{*}$ \\
\hline & {$[0.001]$} & {$[0.001]$} & {$[0.001]$} & {$[0.002]$} & {$[0.001]$} & {$[0.001]$} & {$[0.014]$} & {$[0.005]$} & {$[0.002]$} & {$[0.002]$} \\
\hline Age & -0.002 & 0.002 & 0.003 & 0.002 & -0.001 & -0.002 & $0.014^{*}$ & 0.003 & 0.002 & 0.003 \\
\hline & {$[0.003]$} & {$[0.003]$} & {$[0.003]$} & {$[0.003]$} & {$[0.002]$} & {$[0.003]$} & {$[0.008]$} & {$[0.015]$} & {$[0.005]$} & {$[0.004]$} \\
\hline Foreign & $0.965^{* * *}$ & $0.537^{* * *}$ & -0.085 & 0.171 & $0.882^{* * *}$ & $0.601^{* * *}$ & -0.501 & 0.181 & $1.614^{* * *}$ & $1.168^{* * *}$ \\
\hline & {$[0.157]$} & {$[0.118]$} & {$[0.146]$} & {$[0.145]$} & {$[0.143]$} & {$[0.112]$} & {$[0.910]$} & {$[0.355]$} & {$[0.232]$} & {$[0.124]$} \\
\hline Pseudo R & 0.220 & 0.241 & 0.077 & 0.107 & 0.166 & 0.178 & 0.333 & 0.518 & 0.341 & 0.418 \\
\hline Obs. & 17605 & 29059 & 17836 & 29092 & 17673 & 28954 & 260 & 6460 & 10668 & 19106 \\
\hline
\end{tabular}

Notes: ${ }^{*} p<0.10,{ }^{* *} p<0.05,{ }^{* *} p<0.01$, weighted logit regression with clustered robust standard errors. All specifications contain a full set of sector, country and time fixed effects, which are jointly significant $(p=0.000)$. Dummies are not reported for the clarity, but available from authors upon request. Classification of high and low-income countries follows World Bank procedure with upper middle countries being classified as high-income and lowers middle as low-income.

Source: own computation.

Table 6. Participation in exporting and indirect exporting: manufacturing versus service sectors

\begin{tabular}{|l|c|c|c|c|}
\hline & \multicolumn{2}{|c|}{ Exporting } & \multicolumn{2}{c|}{ Exporting indirectly } \\
\hline \multicolumn{1}{|c|}{ Sector } & Manufacturing & Services & Manufacturing & Services \\
\hline & $\mathbf{( 1 )}$ & $(\mathbf{2})$ & $\mathbf{( 3 )}$ & $\mathbf{( 4 )}$ \\
\hline Prod & $0.160^{* * *}$ & $0.168^{* *}$ & 0.036 & $0.107^{* * *}$ \\
\hline & {$[0.031]$} & {$[0.027]$} & {$[0.028]$} & {$[0.036]$} \\
\hline Size & $0.741^{* * *}$ & $0.301^{* * *}$ & $0.293^{* * *}$ & $0.261^{* *}$ \\
\hline & {$[0.029]$} & {$[0.039]$} & {$[0.034]$} & {$[0.046]$} \\
\hline Age & 0.002 & 0.001 & 0.003 & -0.000 \\
\hline & {$[0.002]$} & {$[0.003]$} & {$[0.002]$} & {$[0.003]$} \\
\hline Foreign & $0.715^{* * *}$ & $0.777^{* * *}$ & -0.006 & $0.515^{* * *}$ \\
\hline & {$[0.084]$} & {$[0.111]$} & {$[0.101]$} & {$[0.134]$} \\
\hline Pseudo $\mathrm{R}^{2}$ & 0.265 & 0.171 & 0.107 & 0.127 \\
\hline Obs & 50401 & 32498 & 50674 & 32554 \\
\hline
\end{tabular}

Notes: ${ }^{\star} p<0.10,{ }^{* *} p<0.05,{ }^{* *} p<0.01$, weighted logit regression with clustered robust standard errors. All specifications contain a full set of sector, country and time fixed effects, which are jointly significant $(p=0.000)$. Dummies are not reported for clarity but are available from author on request.

Source: own computation. 
Table 7. Intensity of internationalisation

\begin{tabular}{|l|c|c|c|c|c|}
\hline & Exporting & $\begin{array}{c}\text { Exporting } \\
\text { indirectly }\end{array}$ & Importing & $\begin{array}{c}\text { Importing } \\
\text { indirectly }\end{array}$ & $\begin{array}{c}\text { Exporting and } \\
\text { importing }\end{array}$ \\
\hline & $(\mathbf{1})$ & $(\mathbf{2})$ & $(3)$ & $\mathbf{( 4 )}$ & $\mathbf{( 5 )}$ \\
\hline Prod $_{\mathrm{i}}$ & $-0.035^{* *}$ & $-0.064^{* *}$ & 0.023 & -0.010 & 0.011 \\
\hline Size $_{\mathrm{i}}$ & {$[0.017]$} & {$[0.025]$} & {$[0.017]$} & {$[0.016]$} & {$[0.009]$} \\
\hline & $0.104^{* * *}$ & -0.007 & -0.017 & $-0.066^{* * *}$ & $0.058^{* * *}$ \\
\hline UnSkill $_{\mathrm{i}}$ & {$[0.021]$} & {$[0.030]$} & {$[0.014]$} & {$[0.022]$} & {$[0.015]$} \\
\hline & $-0.001^{*}$ & -0.001 & -0.000 & -0.000 & -0.001 \\
\hline Age $_{\mathrm{i}}$ & {$[0.001]$} & {$[0.001]$} & {$[0.000]$} & {$[0.001]$} & {$[0.000]$} \\
\hline & $-0.006^{* * *}$ & $-0.004^{*}$ & -0.001 & -0.002 & $-0.003^{* * *}$ \\
\hline Foreign $_{\mathrm{i}}$ & {$[0.002]$} & {$[0.002]$} & {$[0.001]$} & {$[0.001]$} & {$[0.001]$} \\
\hline & $0.205^{* * *}$ & 0.106 & $0.143^{* * *}$ & 0.067 & $0.159^{* * *}$ \\
\hline $\mathrm{R}^{2}$ & {$[0.063]$} & {$[0.089]$} & {$[0.036]$} & {$[0.076]$} & {$[0.032]$} \\
\hline $\mathrm{N}$ & 0.250 & 0.238 & 0.197 & 0.231 & 0.306 \\
\hline
\end{tabular}

Notes: OLS with clustered robust standard errors. Observations weighted by strata. ${ }^{\star} p<0.10$, ${ }^{* *} p<0.05,{ }^{* *} p<0.01$. All specifications contain a full set of sector, country and time fixed effects, which are jointly significant $(p=0.000)$. Dummies are not reported for clarity but are available from author on request.

Source: own computation.

Table 8. Intensity of internationalisation: high-income versus low-income countries

\begin{tabular}{|l|c|c|c|c|c|c|c|c|c|c|}
\hline & \multicolumn{2}{|c|}{ Exporting } & \multicolumn{2}{c|}{$\begin{array}{c}\text { Exporting } \\
\text { indirectly }\end{array}$} & \multicolumn{2}{c|}{ Importing } & \multicolumn{2}{|c|}{$\begin{array}{c}\text { Importing } \\
\text { indirectly }\end{array}$} & \multicolumn{2}{c|}{$\begin{array}{c}\text { Exporting and } \\
\text { importing }\end{array}$} \\
\hline Income & High & Low & High & Low & High & Low & High & Low & High & Low \\
\hline & $\mathbf{( 1 )}$ & $\mathbf{( 2 )}$ & $\mathbf{( 3 )}$ & $\mathbf{( 4 )}$ & $\mathbf{( 5 )}$ & $\mathbf{( 6 )}$ & $\mathbf{( 7 )}$ & $\mathbf{( 8 )}$ & $\mathbf{( 9 )}$ & $\mathbf{( 1 0 )}$ \\
\hline Prod & $-0.041^{*}$ & -0.015 & $-0.153^{* * *}$ & -0.023 & $0.034^{* *}$ & 0.027 & -0.016 & 0.004 & 0.004 & $0.021^{*}$ \\
\hline & {$[0.023]$} & {$[0.022]$} & {$[0.037]$} & {$[0.024]$} & {$[0.015]$} & {$[0.017]$} & {$[0.027]$} & {$[0.016]$} & {$[0.015]$} & {$[0.011]$} \\
\hline Size & $0.150^{* * *}$ & $0.070^{* *}$ & 0.031 & -0.030 & $-0.035^{*}$ & -0.005 & $-0.067^{* *}$ & $-0.063^{* *}$ & $0.056^{* *}$ & $0.065^{* * *}$ \\
\hline & {$[0.032]$} & {$[0.027]$} & {$[0.042]$} & {$[0.039]$} & {$[0.018]$} & {$[0.018]$} & {$[0.029]$} & {$[0.029]$} & {$[0.025]$} & {$[0.016]$} \\
\hline Unskill & -0.000 & $-0.002^{* *}$ & 0.001 & $-0.002^{*}$ & -0.000 & 0.000 & -0.001 & -0.000 & -0.000 & $-0.001^{*}$ \\
\hline & {$[0.001]$} & {$[0.001]$} & {$[0.001]$} & {$[0.001]$} & {$[0.001]$} & {$[0.000]$} & {$[0.001]$} & {$[0.001]$} & {$[0.001]$} & {$[0.001]$} \\
\hline Age & $-0.006^{* * *}$ & $-0.006^{* *}$ & -0.001 & $-0.007^{* *}$ & 0.000 & -0.001 & -0.001 & -0.001 & $-0.003^{* *}$ & $-0.003^{* *}$ \\
\hline & {$[0.002]$} & {$[0.003]$} & {$[0.002]$} & {$[0.003]$} & {$[0.001]$} & {$[0.001]$} & {$[0.002]$} & {$[0.002]$} & {$[0.001]$} & {$[0.001]$} \\
\hline Foreign & $0.253^{* *}$ & $0.157^{* *}$ & 0.030 & 0.111 & $0.165^{* *}$ & $0.119^{* * *}$ & 0.086 & 0.039 & $0.147^{* * *}$ & $0.160^{* * *}$ \\
\hline & {$[0.096]$} & {$[0.078]$} & {$[0.126]$} & {$[0.114]$} & {$[0.059]$} & {$[0.044]$} & {$[0.124]$} & {$[0.097]$} & {$[0.046]$} & {$[0.047]$} \\
\hline Pseudo $\mathrm{R}^{2}$ & 0.220 & 0.241 & 0.077 & 0.107 & 0.166 & 0.178 & 0.333 & 0.518 & 0.341 & 0.418 \\
\hline Obs. & 17605 & 29059 & 17836 & 29092 & 17673 & 28954 & 260 & 6460 & 10668 & 19106 \\
\hline
\end{tabular}

Notes: OLS with clustered robust standard errors. Observations weighted by strata. ${ }^{\star} p<0.10$, ${ }^{* *} p<0.05,{ }^{* * *} p<0.01$. All specifications contain a full set of sector, country and time fixed effects, which are jointly significant $(p=0.000)$. Dummies are not reported for clarity but are available from author on request.

Source: own computation 


\section{References}

Chaney, T. (2008). Distorted gravity: the intensive and extensive margins of international trade. The American Economic Review, 98(4), 1707-1721.

Cieślik, A., Michałek, A., \& Michałek, J. J. (2014). European integration and firm's export performance in the new EU member countries. The Poznań University of Economics Review, 14(4), 38-53.

Eaton, J., Kortum, S., \& Kramarz, F. (2004). Dissecting trade: firms, industries and export destinations. American Economic Review, 94, 150-154.

Heckman, J. J. (1979). Sample selection bias as a specification error. Econometrica, 47, 153-161.

Hagemejer J. (2015). Productivity spillovers in the GVC. The case of Poland and the New EU Member States (WNE Working Paper No. 42(2015)/190). University of Warsaw, Faculty of Economic Sciences.

Helpman, E., Melitz, M., \& Rubinstein, Y. (2008). Estimating trade flows: trading partners and trading volumes. The Quarterly Journal of Economics, 123(2), 441-487.

Helpman E., Melitz M. J., Yeaple S. R., (2004). Exports versus FDI with heterogenous firms. American Economic Review, 94, 300-316.

Hummels, D., \& Klenow, P. J. (2005). The variety and quality of a nation's exports. The American Economic Review, 95(3), 704-723.

Katayama, H., Lu, S., \& Tybout, J. R. (2009). Firm-level productivity studies: illusions and a solution. International Journal of Industrial Organization, 27(3), 403-413.

Kordalska, A., Wolszczak-Derlacz, J., \& Parteka, A. (2016). Global value chains and productivity gains: a cross-country analysis. Collegium of Economic Analysis Annals, 41, 11-28.

Krugman, P. (1979). Increasing returns, monopolistic competition, and international trade. Journal of International Economics, 9(4), 469-479.

Krugman, P. (1980). Scale economies, product differentiation, and the pattern of trade. American Economic Review, 70(5), 950-959.

Levinsohn, J., \& Petrin, A. (2003). Estimating production functions using inputs to control for unobservables. Review of Economic Studies, 70(2), 317-341.

Martins, P. S., \& Yang, Y. (2009). The impact of exporting on firm productivity: a meta-analysis of the learning-by-exporting hypothesis. Review of World Economics, 145(3), 431-445.

Melitz, M. (2003). The impact of trade on intra-industry reallocations and aggregate industry productivity. Econometrica, 71, 1695-1725.

Melitz, M. J., \& Redding, S. J. (2014). Heterogeneous firms and trade. Handbook of International Economics, 4, 1-54.

Michel, B., Rycx, F. (2014). Productivity gains and spillovers from offshoring. Review of International Economics, 22(1), 73-85.

OECD. (2001). Measuring productivity: measurement of aggregate and industry-level productivity growth, OECD Manual, Paris: OECD.

OECD, and World Bank Group Bank (2015). Inclusive Global Value Chains. Policy options in trade and complementary areas for GVC Integration by small and medium enterprises and low-income developing countries. Retrieved from https://www.oecd. org/trade/OECD-WBG-g20-gvc-report-2015.pdf 
OECD. (2017). OECD Compendium of Productivity Indicators 2017. OECD Publishing Paris.

Ohlin, B. (1933). International and interregional trade. Cambridge: Harvard Economic Studies.

Ranjan, P., \& Raychaudhuri, J. (2016). The "new-new" trade theory: a review of the literature. In International Trade and International Finance (3-21). Springer India.

Ricardo, D. (1821). On the principles of political economy, and taxation. London: John Murray.

Schank, T., Schnabel, C., \& Wagner, J. (2010). Higher wages in exporting firms: self-selection, export effect, or both? First evidence from linked employer-employee data. Review of World Economics, 146(2), 303-322.

Schwörer, T. (2013). Offshoring, domestic outsourcing and productivity: evidence for a number of European countries. Review of World Economics, 149, 131-149.

Silva, J. S., Tenreyro, S., \& Wei, K. (2014). Estimating the extensive margin of trade. Journal of International Economics, 93(1), 67-75.

Singh, T. (2010). Does international trade cause economic growth? A survey. The World Economy, 33(11), 1517-1564.

Smith, A. (1776). An inquiry into the nature and causes of the wealth of nations, Vol. 1. London: W. Strahan and T. Cadell.

Vogel, A., \& Wagner, J. (2010). Higher productivity in importing German manufacturing firms: self-selection, learning from importing, or both?. Review of World Economics, 145(4), 641-665.

Wagner, J. (2007). Exports and productivity: a survey of the evidence from firm-level data. The World Economy, 30(1), 60-82.

Wagner, J. (2012). International trade, firm performance: a survey of empirical studies since 2006. Review of World Economics/Weltwirtschaftliches Archiv, 148(2), 235-267.

World Bank, (2009). Enterprise Survey and indicator surveys. Sampling methodology: https://www.enterprisesurveys.org/ /media/GIAWB/EnterpriseSurveys/ Documents/Methodology/Sampling_Note.pdf

World Bank, (2011). World Bank's Enterprise Survey understanding the questionnaire. Retrieved from https://www.enterprisesurveys.org/ /media/GIAWB/ EnterpriseSurveys/Documents/Methodology/Questionnaire-Manual.pdf 